\title{
Information für deutschsprachige Autoren
}

Frau Susan Griesbach, die seit der zweisprachigen Erscheinungsweise dieser Zeitschrift verläßlich und sachkundig sämtliche englischen Texte sprachlich bearbeitet, hat freundlicherweise für die deutschsprachigen Autoren Übersetzungshilfen

(Deutsch/Englisch) kritisch zusammengestellt und kommentiert.

Suggested translation aids (D/E) for orthodontists

Never use computerized translation programs. They are far from being perfected - in fact they are something of a disaster area.

On the other hand, the computerized spelling check is a good backup measure (though not a substitute for a careful control by the author).

\section{General medical/dental terminology}

The best of these dictionaries is still

Bunjes, Wörterbuch der Medizin und Pharmazeutik

Thieme Verlag, ISBN 3-13-370503-2, DM 168,- per valume (D/E or E/D) although the currently available D/E edition dates from 1981.

Also quite good:

Dressler, Klinische Medizin,

Deutsch-Englisch, VCH Verlagsgesellschaft,

ISBN 3-527-15464-7

\section{Specialized dental terminology}

Very highly recommended:

FDI Lexicon of English Dental Terms

with their equivalents in Español, Deutsch, Français

Compiled by World Dental Federation (FDI), 7 Carlisle Street, London W1V 5RG, United Kingdom

(CAVE: Bookshops have great difficulty in obtaining this book; many refuse to try any more! It is best to order direct, quoting credit card details. Even then, the delivery period is rather long.)

Just published:

Reuter/Reuter

Dictionary of Dentistry/Wörterbuch Zahnmedizin

Thieme leximed 1999, DM 148,-
This is still "hot from the press" (September 1999). However, one team of orthodontists reports that many terms in everyday use in orthodontics are missing (e.g. Fernröntgen[seiten]bild, Durchzeichnung, distalisieren, Palatinalbogen, Kieferwinkel, Abdrucklöffel, Nichtanlage, Zahnunterzahl, Bogen[draht]) or are unsuitably translated (e.g Löffel, LKG-Spalte, Tiefbiß). Many of these terms are to be found, correctly translated, even in a good medical dictionary.

Very promising:

Bucksch, Dentalwörterbuch D/E, E/D (Dictionary of Dental Practice)

(The long-awaited 2nd edition - the present edition in Verlag Neuer Merkur dates from $1978^{\circ}$ - is due to be published this autumn by Thieme. It will be reviewed in the J Orofac Orthop/Fortschr Kieferorthop.)

Thieme is thus publishing 2 dental dictionaries within a very short period. The reason given is that the Bucksch dictionary is ,more technically orientated" than the Reuter/Reuter dictionary, a claim that is definitely justified even by the original edition.

\section{Very helpful books in English}

Harty, Concise Illustrated Dental Dictionary, Wright (in Reed Elsevier group), ISBN 0-7236-1014-2, ca. DM 75,-

(This book has good, clear definitions and outstandingly good illustrations; among the appendices are tooth notation, dental rotary instruments, radiographic technique and anatomy, wire gauges. It is an excellent help in checking out terminology in cases of doubt.)

Mitchell/Mitchell, Oxford Handbook of Clinical Dentistry, Third Edition, Oxford University Press, ISBN 0-19-262963-8 (At DM 49,80 this dental handbook has a fantastic price/performance ratio. It has a very clear layout and is wonderfully helpful.) 